\title{
Efficacy and safety assessment of microbiological feed additive for chicken broilers in tolerance studies
}

\author{
Marta Kupryś-Caruk $^{1}$, Monika Michalczuk ${ }^{2}$, Beata Chabłowska ${ }^{1}$, \\ Ilona Stefańska ${ }^{3}$, Danuta Kotyrba ${ }^{1}$, Marta Parzeniecka-Jaworska ${ }^{4}$ \\ ${ }^{1}$ Department of Fermentation Technology, \\ prof. W. Dąbrowski Institute of Agricultural and Food Biotechnology, 02-532 Warsaw, Poland \\ ${ }^{2}$ Department of Specific Animal Breeding, Faculty of Animal Sciences, \\ Warsaw University of Life Sciences, 02-786 Warsaw, Poland \\ ${ }^{3}$ Department of Preclinical Science, ${ }^{4}$ Department of Pathology and Veterinary Diagnostics, \\ Faculty of Veterinary Medicine, Warsaw University of Life Sciences, 02-776 Warsaw, Poland \\ marta.kuprys@ibprs.pl
}

Received: December 19, $2017 \quad$ Accepted: March 12, 2018

\begin{abstract}
Introduction: One aim of the study was to evaluate the impact when added to feed of the two potentially probiotic strains of lactic acid bacteria (LAB) Lactobacillus plantarum K KKP 593/p and Lactobacillus rhamnosus KKP 825 on production performance, health, and the composition of gut microbiota. The complementary aim was to assess the safety of these strains in broiler rearing. Material and Methods: A total of 500 one-day-old Ross 308 chicks were divided into four groups. The experimental factor was the admixture of bacterial preparation to the feed at different doses: the recommended maximum dose, a dose ten times higher, the recommended minimum dose, and a zero dose for the control group not receiving bacteria. Results: Addition of bacteria to the diets did not have a significant effect on the final body weight, final body weight gain, nor total feed intake or feed conversion. However, lactic acid bacteria had a positive effect on chicken health. Mortality among chickens fed with LAB was reduced. Moreover, LAB feeding inhibited the growth of Salmonella spp. and Clostridium perfringens in the intestines. There were no significant differences in chicken performance by dose of bacteria in the feed. The group dosed with LAB ten times higher than the recommended maximum did not demonstrate changes in biochemical or haematological parameters of blood compared to the remaining groups. Conclusion: Feeding chicken broilers with two potentially probiotic LAB strains is safe and impacts animal health positively.
\end{abstract}

Keywords: broiler chickens, probiotics, feeding, blood parameters, tolerance study.

\section{Introduction}

Nowadays probiotics are widely used in animal nutrition, as evidenced by the variety of different types of bacterial feed additives on the EU market. Currently probiotics are used in feeding of poultry, pigs, sows, hens, turkeys, fattening cattle, dairy cows, lambs, sheep, goats, and rabbits (20). Probiotics are live microorganisms, mainly Gram-positive bacteria (Lactobacillus, Lactococcus, Enterococcus, Carnobacterium, Streptococcus, and Bacillus), gramnegative bacteria (Shewanella, Aeromonas, Vibrio, Enterobacter, and Pseudomonas), and fungi (Saccharomyces, Debaryomyces, and Phaffia). The mechanisms by which probiotics benefit the host's health are known and have been confirmed by numerous studies (4). Probiotics can primarily be used to protect against bacterial pathogens, which is of great importance in large-scale rearing, where animals are exposed to stressful conditions and, for that reason, are more susceptible to infections (15). Colonisation of animals' intestines by potentially pathogenic bacterial strains can be limited by competition with indigenous intestinal flora, mainly lactic acid bacteria (LAB) (8).

In order for a given probiotic strain to be marketed as feed additive, it must pass through the procedure for their authorization under Regulation (EC) No 1831/2003. Article 6 and Annex I of the Regulation provide categories and functional groups of feed additives. Probiotics are classified under the category 
"zootechnical additives". In the case of registration of probiotic strains, the efficacy test of the additive must be performed on the target species. The positive effect of the probiotic supplement should be demonstrated by a decrease in the morbidity or mortality of the species tested and a more complete use of feed ingredients (20). Moreover, Commission Regulation (EC) No 429/2008 provides rules for the implementation of Regulation (EC) No 1831/2003 and imposes the obligation to provide a safety assessment (tolerance test) of the use of the probiotic additive by the target animals at the highest proposed levels in feed or water and at multiple levels.

The aim of a tolerance test is to provide a limited evaluation of the short-term toxicity of the additive to the target animals. It is also used to establish a margin of safety, if the additive is consumed at higher doses than recommended. Such tolerance tests must be conducted to provide evidence for the safety of the probiotic for the target animal. Test animals should be routinely monitored for visual evidence of clinical effects, performance characteristics, product quality, haematology and routine blood chemistry (7). Particular attention should also be paid to the acquisition of resistance to antibiotics and the transfer of resistance genes by probiotic strains used as feed additives (20).

The aim of the study was to provide an efficacy and safety assessment of the use of potentially probiotic lactic acid bacterium strains in the feed during broiler chickens rearing in the tolerance test.

\section{Material and Methods}

Birds and management. The experiment lasted for 42 days. Chickens were reared in the production hall in the Agricultural Experimental Station Obory-Wilanów (in Warsaw) owned by Warsaw University of Life Sciences (SGGW). A total of 500 one-day-old Ross 308 chicks, initially weighing $44.4 \pm 0.58 \mathrm{~g}$, were divided into four equal groups: three experimental groups: Max, 10Max, Min, and one control group $\mathrm{K}$ (in five repetitions). The birds were kept on straw litter in 20 pens ( 25 birds in each pen at a stocking density of 11.4 birds per $\mathrm{m}^{2}$ ). Air temperature, relative humidity and cooling conditions were the same for all the treatment groups. On the first day of life the chickens were vaccinated against the following diseases: Marek's disease and Gumboro disease with Vaxxitek IBD vaccine (Merial, Germany) by injection; infectious bronchitis /IB/ with Cevac Bron $120 \mathrm{~L}$ vaccine, and Newcastle disease /ND/ with Cevac Vitapest L (Ceva Animal Health, France) vaccine by the spray method. On the $15^{\text {th }}$ day of life the birds were vaccinated against infectious bronchitis /IB/ with Nobilis 4/91 vaccine (Intervet, Poland).

Feeding programme. The broilers were fed according to the following feeding programme: starter 1-21 days, grower 21-35 days, and finisher 36-42 days. Feed and water were provided ad libitum. Feed for all groups was made in mashed form from the same compounds. The feed mixtures comprised grain meal (maize or wheat), soybean meal, sunflower meal, rapeseed meal, and mineral feeds (dicalcium phosphate, sodium bicarbonate, sodium chloride, and fodder chalk). In grower and finisher feed Premix Monteban (Elanco, USA) was also included. The experimental factor was the application of a bacterial preparation to the feed at different doses. The bacterial preparation (in the form of a lyophilisate) was produced in the Department of Fermentation Technology in the prof. Wacław Dąbrowski Institute of Agricultural and Food Biotechnology in Warsaw and consisted of two potentially probiotic LAB strains: Lactobacillus plantarum K KKP 529/p and Lactobacillus rhamnosus KKP 825

The experimental design was as follows:

$\mathrm{K}$ : control group (without addition of preparation to feed);

Max: fed the maximum dose of the preparation as recommended by the producer;

Min: fed the minimum dose of the preparation as recommended by the producer;

10Max: fed a dose of the preparation ten times higher than the maximum recommended dose (tolerance group).

The number of live bacteria in the preparation was $1.0 \times 10^{9} \mathrm{cfu}^{-1}$. The quantities of active agents in the preparation (live lactic acid bacteria) introduced to the diets and the expected daily intake of bacteria (calculated on the basis of predetermined feed intake by birds) are presented in Table 1.

Table 1. Calculated quantities of preparation and bacteria in feed and suspected daily intake of the preparation and bacteria by a chicken

\begin{tabular}{|c|c|c|c|c|}
\hline & \multicolumn{2}{|c|}{ The amount in feed } & \multicolumn{2}{|c|}{ Daily intake } \\
\hline Experimental group & $\begin{array}{l}\text { Preparation } \\
\left(\mathrm{g} \mathrm{kg}^{-1}\right)\end{array}$ & $\begin{array}{l}\text { Bacteria } \\
\left(\mathrm{cfu} \mathrm{g}^{-1}\right)\end{array}$ & $\begin{array}{l}\text { Preparation } \\
\left(\text { g piece }^{-1} \text { day }^{-1}\right)\end{array}$ & $\begin{array}{l}\text { Bacteria } \\
\left(\text { cfu piece }^{-1} \text { day }^{-1}\right)\end{array}$ \\
\hline \multicolumn{5}{|c|}{ Starter } \\
\hline Max & 1.0 & $1.0 \times 10^{6}$ & 0.035 & $3.5 \times 10^{7}$ \\
\hline 10Max & 10 & $1.0 \times 10^{7}$ & 0.350 & $3.5 \times 10^{8}$ \\
\hline Min & 0.5 & $5.0 \times 10^{5}$ & 0.018 & $1.8 \times 10^{7}$ \\
\hline \multicolumn{5}{|c|}{ Grower } \\
\hline Max & 0.3 & $3.0 \times 10^{5}$ & 0.036 & $3.6 \times 10^{7}$ \\
\hline 10Max & 3.0 & $3.0 \times 10^{6}$ & 0.360 & $3.6 \times 10^{8}$ \\
\hline Min & 0.15 & $1.5 \times 10^{5}$ & 0.018 & $1.8 \times 10^{7}$ \\
\hline \multicolumn{5}{|c|}{ Finisher } \\
\hline Max & 0.2 & $2.0 \times 10^{5}$ & 0.043 & $4.3 \times 10^{7}$ \\
\hline 10Max & 2.0 & $2.0 \times 10^{6}$ & 0.430 & $4.3 \times 10^{8}$ \\
\hline Min & 0.1 & $1.0 \times 10^{5}$ & 0.021 & $2.2 \times 10^{7}$ \\
\hline
\end{tabular}


Observations. All broilers were individually weighed at the start of the experiment and then at the age of 21, 35, and 42 days. After 21, 35, and 42 days of rearing, the total feed consumption of starter, grower, and finisher diets was determined for each group. Based on these data, the mean live body weight of chickens, feed consumption, and feed conversion after all rearing periods were calculated. Mortality was monitored during the whole rearing period.

At the end of rearing (42 day) 12 broilers ( 6 males and 6 females) were taken from each group for slaughter. Blood was sampled from the wing vein for haematology and routine blood chemistry. A whole small intestine was collected for microbial analysis.

Microbiological analysis. After slaughtering, the whole content of the small intestine was collected, weighed, diluted 10 times with saline, and then again diluted from $10^{-1}$ to $10^{-5}$. From the last three dilutions $0.1 \mathrm{~mL}$ was plated onto the appropriate medium for enumeration of intestinal microbiota (in triplicate).

Qualitative and quantitative microbiological studies included the following indicators:

- total number of Enterobacteriaceae -VRBG medium (BioMérieux, France), deep culture, incubation at $37^{\circ} \mathrm{C}$;

- E. coli - TBX Agar medium (Bio-Rad, France), $42^{\circ} \mathrm{C}$, deep culture;

- Enterococcus spp. - Slanetz-Bartley medium (Merck, Germany), surface culture at $37^{\circ} \mathrm{C}$ under microaerophilic conditions $\left(5 \% \mathrm{O}_{2}\right)$ in an incubator (Cellhouse, Heto-holten, Denmark) with the regulation of oxygen amount using $\mathrm{CO}_{2}$;

- Lactobacillus spp. - MRS medium (SigmaAldrich, USA), $37^{\circ} \mathrm{C}$, deep culture;

- Clostridium perfringens - TSC medium (Oxoid, U.K.), $37^{\circ} \mathrm{C}$, deep culture, plates were flooded with a thin layer of agar.

The presence of bacteria from the Salmonella genus was also determined according to the PN-EN ISO 6579: 2003 standard (valid during the study). Initially the content of the intestine was diluted 10 times in buffered peptone water (Merck, Germany) and preincubated for $20 \mathrm{~h}$ at $37^{\circ} \mathrm{C}$. After incubation, it was cultured on Modified Semi-solid Rappaport Vassiliadis Base (Oxoid, U.K.) (applying by spotting $100 \mu \mathrm{l}$ onto the plates) and incubated for $24 \mathrm{~h}$ at $41^{\circ} \mathrm{C}$. Positive samples were then transferred to Brilliance Agar (Oxoid) (reducing inoculation). After reincubation on Brilliance Agar for $20 \mathrm{~h}$ at $41^{\circ} \mathrm{C}$ and obtainment of clean colonies, bacteria were identified using Api 20 E (BioMérieux, France).

Blood analysis. Blood samples $(3 \mathrm{~mL})$ were taken into EDTA polystyrene tubes for morphological testing. All blood samples were collected at the same time to minimise any changes in blood composition caused by circadian rhythm. Samples were stored in containers with ice to avoid protein denaturation and were delivered to a specialised veterinary diagnostic laboratory within two hours where blood smear examinations and morphological analyses were performed.

Samples of collected blood for biochemical analysis were centrifuged at $20^{\circ} \mathrm{C}(3,000 \mathrm{rpm})$ for $10 \mathrm{~min}$. Plasma was stored at $-20^{\circ} \mathrm{C}$ until analysis which was performed with the use of the following commercial tests: aspartate aminotransferase (AST) (kinetic method, cat. no. A7560), creatine kinase (CK) (kinetic method, cat. no. C7512), total protein (burette reaction, cat. no. T7528), uric acid (cat. no. U7580), and bile acids (enzymatic method, cat. no. DZ042A-K) (Pointe Scientific, USA).

Statistical methods. Statistical analysis consisted of calculating the mean values and standard deviations of the tested parameters. The significance of differences in mean values was determined using the ANOVA test and post-hoc Tukey test or ANOVA rank KruskalWallis test and multiple comparisons (in the case when the assumptions of the parametric analysis was not fulfilled, i.e. the assumption about the normality and variance homogeneity). The significance level was $\alpha=0.05$.

\section{Results}

Performance. Compared to the control group, bacteria addition to the feed increased the live body weight of chickens after the first period of rearing (at 21 days). After 21 days of rearing the average body weight of chickens in the use-level (Max and Min) and tolerance groups (10Max) was significantly higher than in the control group (K) (Table 2).

The final live body weight of chickens (after 42 days of rearing) in the $10 \mathrm{Max}$ and Min groups was significantly higher than in the control group $(\mathrm{K})$, but there was no significant difference between the final body weight of chickens of the use-level (Max) and control (K) groups. There was also no significant difference between the final average live body weight of chickens from the tolerance (10Max) and use-level (Min) groups.

Body weight gain between all examined groups during the second (22-35 days) and the final (36-42 days) rearing periods did not differ significantly, and variation between body weight gains was confined to the first feeding period. After 21 days of rearing body weight gain was the highest in the Min group and significantly higher than in the control group. Body weight gain in the Max and 10Max groups was slightly but not significantly higher than in the control group.

After 42 days of rearing it was observed that the total body weight gain was the highest in the Min group but the body weight gain in this group did not differ significantly from the rest of the groups (Table 2).

Mortality. Mortality among chickens from experimental groups fed bacterial preparation was lower than in the control group. Mortality among chickens from the control group was the highest at $3.2 \%$. Among chickens from the tolerance group (10Max) this 
parameter was no different from its value in the Max group, and lower than it was in the Min group (Table 3).

Generally mortality was low so no veterinary interventions were required. The reasons for losses (stated by the veterinarian) were: gout, colibacillosis, anaerobes enteritis and inflammation of the gall bladder.

Feed intake. Total feed consumption during the 42 days of the growing period exceeded $4.5 \mathrm{~kg}$ per chicken. There were no significant differences between total feed intakes among the experimental groups fed bacterial preparation. A difference was observed in the case of total feed intake per chicken between the control $(\mathrm{K})$ and Max groups (chickens from the control group consumed less feed). In all groups chickens ate a similar amount of starter, grower, and finisher feed (Table 4).

In the case of feed conversion only one difference was observed, and it concerned starter feed conversion between the control and Max groups (conversion of starter feed in the control group was significantly lower than in the Max group) (Table 4).

Table 2. Effects of experimental feeding on body weight and body weight gain of broiler chickens (g)

\begin{tabular}{|c|c|c|c|c|c|c|c|c|}
\hline \multirow{3}{*}{ Rearing period } & \multicolumn{2}{|c|}{$\mathrm{K}$} & \multicolumn{2}{|c|}{ Max } & \multicolumn{2}{|c|}{ 10Max } & \multicolumn{2}{|c|}{ Min } \\
\hline & $\begin{array}{l}\text { Mean } \\
\text { value }\end{array}$ & SD & $\begin{array}{l}\text { Mean } \\
\text { value }\end{array}$ & SD & $\begin{array}{l}\text { Mean } \\
\text { value }\end{array}$ & SD & $\begin{array}{l}\text { Mean } \\
\text { value }\end{array}$ & SD \\
\hline & \multicolumn{8}{|c|}{ Body weight } \\
\hline $1^{\text {st }}$ day & $44.9^{b}$ & 3.39 & $44.7^{\mathrm{b}}$ & 3.25 & $43.6^{\mathrm{a}}$ & 2.57 & $44.6^{\mathrm{b}}$ & 2.74 \\
\hline $21^{\text {st }}$ day & $698.9^{\mathrm{a}}$ & 90.41 & $739.6^{\mathrm{b}}$ & 99.62 & $737.0^{\mathrm{b}}$ & 99.08 & $765.2^{\mathrm{b}}$ & 110.15 \\
\hline $35^{\text {th }}$ day & $1785.6^{\mathrm{a}}$ & 213.36 & $1811.0^{\mathrm{a}}$ & 251.62 & $1841.9^{\mathrm{ab}}$ & 234.33 & $1910.9^{b}$ & 233.42 \\
\hline \multirow[t]{2}{*}{$42^{\text {nd }}$ day } & $2428.8^{\mathrm{a}}$ & 272.71 & $2450.6^{\mathrm{a}}$ & 320.53 & $2563.1^{\mathrm{b}}$ & 314.74 & $2574.6^{\mathrm{b}}$ & 315.33 \\
\hline & \multicolumn{8}{|c|}{ Body weight gain } \\
\hline $1^{\text {st }}-21^{\text {st }}$ day & $656.7^{\mathrm{a}}$ & 22.79 & $696.3^{\mathrm{ab}}$ & 44.30 & $695.3^{\mathrm{ab}}$ & 33.25 & $727.3^{\mathrm{b}}$ & 7.97 \\
\hline $22^{\text {nd }}-35^{\text {th }}$ day & 1083.8 & 17.27 & 1078.9 & 81.72 & 1105.3 & 57.86 & 1139.0 & 34.23 \\
\hline $36^{\text {th }}-42^{\text {nd }}$ day & 646.6 & 27.88 & 636.0 & 32.64 & 719.9 & 65.4 & 673.1 & 79.64 \\
\hline $1^{\text {st }}-42^{\text {nd }}$ day & $2387.1^{\mathrm{a}}$ & 21.12 & $2481.6^{\mathrm{a}}$ & 77.03 & $2450.2^{\mathrm{a}}$ & 153.5 & $2539.4^{\mathrm{ab}}$ & 68.43 \\
\hline
\end{tabular}

a,b,ab - mean values (in rows) marked with various letters differ at significance level $\alpha=0.05$

$\mathrm{SD}$ - standard deviation

Table 3. Effects of experimental feeding on mortality of broiler chickens (\%)

\begin{tabular}{lllll}
\hline Group & $\mathrm{K}$ & Max & $10 \mathrm{Max}$ & Min \\
\hline Mortality & 3.2 & 1.6 & 1.6 & 2.4 \\
*Culling rate & 1.6 & 0.8 & 0.8 & 0.0 \\
Total losses & 4.8 & 2.4 & 2.4 & 2.4 \\
\hline
\end{tabular}

*Chickens with very low body weight

Table 4. Effects of experimental feeding on feed intake and feed conversion by broiler chickens

\begin{tabular}{|c|c|c|c|c|c|c|c|c|}
\hline \multirow{2}{*}{ Feed } & \multicolumn{2}{|l|}{$\mathrm{K}$} & \multicolumn{2}{|c|}{ Max } & \multicolumn{2}{|c|}{ 10Max } & \multicolumn{2}{|l|}{ Min } \\
\hline & Mean value & SD & Mean value & SD & Mean value & $\mathrm{SD}$ & Mean value & SD \\
\hline \multicolumn{9}{|c|}{ Feed intake, kg per chicken } \\
\hline Starter & 1.36 & 0.06 & 1.46 & 0.06 & 1.4 & 0.08 & 1.47 & 0.09 \\
\hline Grower & 2.15 & 0.22 & 2.21 & 0.15 & 2.06 & 0.2 & 2.08 & 0.13 \\
\hline Finisher & 1.08 & 0.1 & 1.1 & 0.12 & 1.04 & 0.14 & 1.09 & 0.13 \\
\hline $\begin{array}{l}\text { Total } \\
1^{\text {st }}-42^{\text {nd }} \text { day }\end{array}$ & $4.28^{\mathrm{a}}$ & 0.22 & $4.88^{\mathrm{b}}$ & 0.31 & $4.45^{\mathrm{ab}}$ & 0.27 & $4.54^{\mathrm{ab}}$ & 0.23 \\
\hline \multicolumn{9}{|c|}{ Feed conversion, $\mathrm{kg} \mathrm{kg}^{-1}$ of body weight gain } \\
\hline Starter & $1.96^{\mathrm{a}}$ & 0.2 & $2.48^{\mathrm{b}}$ & 0.3 & $2.09^{\mathrm{ab}}$ & 0.11 & $2.08^{\mathrm{ab}}$ & 0.13 \\
\hline Grower & 1.98 & 0.2 & 2.06 & 0.23 & 1.83 & 0.2 & 1.81 & 0.12 \\
\hline Finisher & 1.67 & 0.14 & 1.71 & 0.13 & 1.51 & 0.14 & 1.66 & 0.29 \\
\hline $\begin{array}{l}\text { Total } \\
1^{\text {st }}-42^{\text {nd }} \text { day }\end{array}$ & 1.89 & 0.13 & 1.97 & 0.1 & 1.81 & 0.13 & 1.84 & 0.08 \\
\hline
\end{tabular}

a,b, ab - mean values (in rows) marked with various letters differ at significance level $\alpha=0.05$

$\mathrm{SD}$ - standard deviation

Table 5. Effects of experimental feeding on biochemical parameters of blood serum of broiler chickens

\begin{tabular}{|c|c|c|c|c|c|c|}
\hline Group & Sex & $\begin{array}{l}\text { AST } \\
\left(\mathrm{U} \mathrm{L}^{-1}\right)\end{array}$ & $\begin{array}{l}\text { Total protein } \\
\left(\mathrm{G} \mathrm{L}^{-1}\right)\end{array}$ & $\begin{array}{l}\mathrm{CK} \\
\left(\mathrm{U} \mathrm{L}^{-1}\right)\end{array}$ & $\begin{array}{l}\text { Bile acids } \\
\left.(\mu \mathrm{mol} \mathrm{L})^{-1}\right)\end{array}$ & $\begin{array}{l}\text { Uric acid } \\
\left(\mathrm{Mg} \mathrm{dL}^{-1}\right)\end{array}$ \\
\hline \multirow[b]{2}{*}{$\mathrm{K}$} & $\hat{0}$ & $379.3 \pm 61.82$ & $55.6 \pm 3.27$ & $9187.5 \pm 1704.24$ & $11.0 \pm 6.14$ & $2.5 \pm 0.93$ \\
\hline & q & $406.1 \pm 47.03^{\mathrm{a}}$ & $27.0 \pm 1.41^{\mathrm{ab}}$ & $9481.4 \pm 2086.87$ & $6.96 \pm 4.93^{\mathrm{a}}$ & $2.9 \pm 1.12$ \\
\hline \multirow{2}{*}{ Max } & $\frac{1}{0}$ & $451.0 \pm 139.77$ & $26.8 \pm 2.71$ & $10586.9 \pm 1090.91$ & $18.4 \pm 2.98$ & $7.7 \pm 1.30$ \\
\hline & 우 & $375.1 \pm 95.7^{\mathrm{a}}$ & $29.8 \pm 2.56^{\mathrm{b}}$ & $9272.8 \pm 1489.16$ & $14.9 \pm 24.79^{b}$ & $4.7 \pm 2.13$ \\
\hline \multirow{2}{*}{ 10Max } & $\pi$ & $405.4 \pm 150.41$ & $24.8 \pm 2.79$ & $9062.0 \pm 2338.61$ & $17.05 \pm 4.62$ & $4.0 \pm 0.72$ \\
\hline & 우 & $563.5 \pm 104.67^{b}$ & $26.0 \pm 1.67^{\mathrm{a}}$ & $11325.0 \pm 602.84$ & $13.67 \pm 2.74^{\mathrm{ab}}$ & $4.4 \pm 1.03$ \\
\hline \multirow{2}{*}{ Min } & $\overline{0}$ & $417.5 \pm 8.55$ & $25.0 \pm 1.73$ & $10355.9 \pm 887.5$ & $10.1 \pm 2.9$ & $2.1 \pm 0.21$ \\
\hline & 웅 & $417.1 \pm 91.2^{\mathrm{ab}}$ & $28.0 \pm 2.58^{\mathrm{ab}}$ & $9953.6 \pm 1654.55$ & $15.25 \pm 3.87^{b}$ & $3.0 \pm 0.95$ \\
\hline
\end{tabular}

a,b, ab - mean values for hens (in columns) marked with various letters differ at significance level $\alpha=0.05$

\pm standard deviation 
Table 6. Effects of experimental feeding on haematology of broiler chickens

\begin{tabular}{|c|c|c|c|c|c|c|c|c|c|}
\hline Group & Sex & $\begin{array}{l}\text { Erythrocyte } \\
\text { Total RBC } \\
\left(\mathrm{T} \mathrm{L}^{-1}\right)\end{array}$ & $\begin{array}{l}\text { Lymphocyte } \\
(\%)\end{array}$ & $\begin{array}{l}\text { Monocyte } \\
(\%)\end{array}$ & $\begin{array}{l}\text { Leukocyte } \\
\text { Total WBC } \\
\left(\mathrm{G} \mathrm{L}^{-1}\right)\end{array}$ & $\begin{array}{l}\text { Haemoglobin } \\
\left(\mathrm{g} \mathrm{dL}^{-1}\right)\end{array}$ & $\begin{array}{l}\text { Haematocrit } \\
\text { PCV }(\%)\end{array}$ & $\begin{array}{l}\text { Heterophil } \\
(\%)\end{array}$ & $\begin{array}{l}\text { Basophil } \\
(\%)\end{array}$ \\
\hline \multirow{2}{*}{$\mathrm{K}$} & $\hat{0}$ & $3.0 \pm 0.53$ & $22.0 \pm 9.17$ & $8.3 \pm 3.25$ & $23.3 \pm 11.18$ & $13.7 \pm 2.25$ & $33.5 \pm 5.6$ & $65.3 \pm 7.77$ & $4.7 \pm 2.31$ \\
\hline & q & $2.5 \pm 0.16$ & $43.0 \pm 0.89$ & $4.3 \pm 1.91$ & $41.7 \pm 5.92$ & $11.7 \pm 1.73$ & $27.4 \pm 6.56$ & $51.0 \pm 1.0$ & $3.7 \pm 1.53$ \\
\hline \multirow{2}{*}{ Max } & $\lambda$ & $2.6 \pm 0.1$ & $20.3 \pm 0.58$ & $9.0 \pm 5.57$ & $15.4 \pm 1.31$ & $12.5 \pm 0.53$ & $29.1 \pm 2.49$ & $59.7 \pm 5.69$ & $9.7 \pm 0.58$ \\
\hline & q & $2.6 \pm 0.2$ & $38.7 \pm 14.57$ & $7.7 \pm 6.51$ & $42.3 \pm 26.15$ & $12.2 \pm 0.75$ & $25.0 \pm 4.36$ & $49.0 \pm 9.54$ & $5.7 \pm 2.08$ \\
\hline \multirow{2}{*}{ 10Max } & $\hat{\sigma}$ & $2.4 \pm 0.14$ & $35.3 \pm 7.02$ & $9.0 \pm 7.55$ & $30.9 \pm 21.92$ & $11.8 \pm 0.6$ & $27.6 \pm 4.36$ & $53.3 \pm 1.15$ & $2.3 \pm 0.58$ \\
\hline & q & $2.8 \pm 0.28$ & $39.0 \pm 7.0$ & $2.3 \pm 1.15$ & $19.1 \pm 6.1$ & $13.3 \pm 1.56$ & $30.9 \pm 3.21$ & $51.7 \pm 6.51$ & $7.0 \pm 3.61$ \\
\hline \multirow{2}{*}{ Min } & 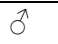 & $2.8 \pm 0.42$ & $22.7 \pm 7.09$ & $13.0 \pm 2.65$ & $25.7 \pm 5.49$ & $13.3 \pm 2.26$ & $33.9 \pm 7.23$ & $58.7 \pm 8.33$ & $11.7 \pm 2.08$ \\
\hline & q & $2.7 \pm 0.04$ & $39.3 \pm 14.47$ & $14.3 \pm 2.08$ & $24.3 \pm 5.41$ & $12.6 \pm 0.46$ & $29.1 \pm 1.44$ & $51.3 \pm 11.5$ & $3.3 \pm 1.53$ \\
\hline
\end{tabular}

\pm standard deviation

Table 7. The effects of experimental feeding on microbial analysis of intestinal content after 42 days of chickens rearing (cfu $\mathrm{g}^{-1}$ )

\begin{tabular}{llllll}
\hline Group & E. coli & $\begin{array}{l}\text { Clostridium } \\
\text { perfringens }\end{array}$ & Enterococcus spp. & Salmonella spp. & $\begin{array}{l}\text { Enterobac- } \\
\text { teriaceae }\end{array}$ \\
\hline K & $1.8 \times 10^{7}$ & $2.2 \times 10^{4}$ & $3.8 \times 10^{6}$ & present & $1.0 \times 10^{7}$ \\
Max & $5.2 \times 10^{7}$ & not detected & $7.3 \times 10^{6}$ & not detected & $1.3 \times 10^{7}$ \\
10Max & $1.0 \times 10^{7}$ & not detected & $2.3 \times 10^{6}$ & not detected & $4.6 \times 10^{7}$ \\
Min & $1.0 \times 10^{7}$ & not detected & $7.0 \times 10^{6}$ & not detected & $2.7 \times 10^{7}$ \\
\hline
\end{tabular}

Blood analysis. In the case of females differences between experimental groups were observed in AST, total protein, and bile acid level. In all groups receiving bacteria bile acid levels were slightly higher than that of the control group. In the 10Max group the activity of AST was the highest. However, differentiation in particular biochemical parameters among groups receiving bacteria was not so clear. In the case of males no differences in biochemical parameters were observed between any experimental groups (Table 5).

In the case of haematological parameters of male and female chickens, no significant differences were observed among all experimental groups, $\mathrm{P}>0.05$. There was also no regularity related to the effect of the bacteria added to the diets on the analysed blood parameters. The biggest differences, however statistically insignificant, were observed among female 10Max and Min groups in the case of leukocyte count, which was much lower in these groups compared to the control group. The opposite situation was observed for male 10Max and Min groups, in these groups the content of leukocytes was higher, but still statistically insignificant, compared to the control group. Erythrocyte, lymphocyte, and haemoglobin contents in experimental groups fed bacteria was lower in male groups and higher in female groups compared to the controls, regardless of the dose of bacteria (Table 6).

Microbiological analysis. After 42 days of rearing, microbiological analysis of intestinal contents showed the positive effect of LAB feeding on intestinal microbiota composition. In the intestinal content of chickens from all groups fed bacterial preparation, Clostridium perfringens and Salmonella spp. were not detected. In contrast, in the control group Salmonella enterica subsp. Arizoneae was identified. In all groups the number of bacteria from Lactobacillus genus was approximately an order of magnitude larger than
Enterobacteriaceae. Differences between the number of E. coli and Enterococcus spp. between all experimental groups were not significant $(\mathrm{P}>0.05)$. The mean number of total Enterobacteriaceae was lower than the number of $E$. coli, which belongs to the Enterobacteriaceae family, but the difference in this case was not significant $(\mathrm{P}>0.05)$ (Table 7). However, the lower number of E. coli may result from the fact that the composition of the medium used in this study for Enterobacteriaceae may not be completely optimal for E. coli.

\section{Discussion}

A wide variety of bacterial species are used as probiotics in animal nutrition. Some of them are little known and their use may represent a risk for the target species. The European Food Safety Authority (EFSA) has proposed a system for a pre-market safety assessment of selected groups of microorganisms. Microorganisms which raise safety concerns could be granted QPS status (Qualified Presumption of Safety) and be released from a full safety assessment (toxins or virulence factors should be demonstrated to be absent or of no concern) (21). Lactobacillus plantarum and L. rhamnosus have QPS status, so a full package of toxicological studies is not necessary. No more is required than providing evidence of the safety of using bacteria from these species in the target animal nutrition, as stated in Commission Regulation (EC) No 429/2008.

According to published data the effect of probiotics on the performance of chickens can be various. No positive effects were reported of probiotic Lactobacillus johnsonii strain on weight gain or feed conversion irrespective of the method of its administration (in feed, drinking water, sprayed on litter, or administered directly to the beak) during five weeks of Cobb broiler 
rearing (18). In another study the probiotics Lactobacillus fermentum CCM 7158 and Enterococcus faecium M 74 were added to drinking water and were found to have a positive effect on weight gain compared to Ross 308 broiler chickens not administered probiotics. Probiotics did not affect body dimensions such as length of the back, body circumference, thigh length lower leg (11).

A beneficial effect of probiotics on broiler chicken body weight is not imparted in every instance and depends on the strain used or their particular combination. In this study the impact of the Lactobacillus rhamnosus KKP 825 strain with the Lactobacillus plantarum K KKP 529/p strain on body weight was not as clear as in another study, where Lactobacillus rhamnosus KKP 825 was used in combination with Lactobacillus paracasei KKP 824 and Lactobacillus rhamnosus KKP 826 (5).

The impact of probiotics on feed consumption can also vary depending on the strain used. The feeding of broiler chickens with probiotics resulted in a significant reduction in feed conversion ratio (FCR) and feed consumption per $\mathrm{kg}$ of bird weight gain compared to birds not fed probiotics (16). Meanwhile no effect of probiotic addition to feed (Lb. johnsonii, Lb. crispatus, and $L b$. salivarius) was found on weight gain, feed intake, or FCR of Cobb broiler chickens during five weeks of rearing (17).

An important factor influencing the effectiveness of probiotics in poultry is also the manner and time of their administration. It has been shown that administration of probiotics in feed, compared to drinking water, contributed to a higher mean daily body weight gain (24).

Blood examination is performed as a screening procedure to assess general health. Clinical signs of illness in birds are frequently subtle, so clinical chemistry is necessary to evaluate cellular changes (23). However, it is difficult to compare the results of blood or biochemical parameters of birds with other authors' results because of the influence upon them of diet, age, rearing behaviour, environmental conditions, bird species, and sex $(2,12)$. On the other hand, according to Mazurkiewicz (15), the reference values of blood biochemical parameters for broiler chickens are the same for both sexes.

A key tool in the diagnosis of certain diseases is the determination of enzyme activity in the metabolic profile. Increasing enzyme activity in blood may indicate damage to cellular structures and is proportional to its degree (13). Interpretation of the assay results, however, is difficult due to the wide range of enzyme activities (9).

AST activity is currently considered to be a very sensitive but nonspecific biomarker of hepatocellular disease and is used with the muscle-specific enzyme creatine kinase $(\mathrm{CK})$ to differentiate between liver and muscle damage (10). In the presented study CK was slightly above the reference value in all experimental groups, but AST was at a very high level (384-563.5 $\left.\mathrm{U} \mathrm{L}^{-1}\right)$, much higher than the maximum reference value (15). AST and CK activities increase under pressure (e.g. during slaughtering), and these stressful circumstances being impossible to completely eliminate under experimental conditions may explain these raised levels. AST was also higher than in other described studies $(2,3)$. AST levels did not differ significantly depending on age and sex of chickens (2).

Total protein is important information used to establish supportive care. A decline in total protein may indicate protein-losing nephropathy, enteropathy or liver failure. In the case of total protein insufficiency, increasing dehydration should be investigated (10). Total protein in all experimental groups in this study was consistent with the reference values reported in the literature $(6,15)$.

Uric acid is a product of the catabolic breakdown of proteins and its concentration in serum depends on age, diet, and reproduction (23). According to Harr (10), increasing concentration of uric acid is due to renal disease and decreasing concentration is caused by liver failure. The concentration of uric acid in all experimental groups in this study was in accordance with the references values $(6,15)$, so no damage to said organs was observed. Recorded by Albokhadaim et al., the concentration of uric acid in the blood of four-weekold chickens was independent of sex and was higher than in this study but the chickens were reared at much higher temperature $\left(32^{\circ} \mathrm{C}\right)$ (2). Single administration of probiotic to one-day-old chicks resulted in increasing concentration of blood-carbohydrate, glucose, protein, and haemoglobin levels after 35 days of rearing (22).

In this study no significant escalatory effect of LAB administration on bile acids in chickens' blood was observed. Bile acids are used to assess liver function. A concentration of bile acids higher than $75 \mu \mathrm{mol} \mathrm{L} \mathrm{L}^{1}$ suggests hepatic insufficiency, while a concentration higher than $100 \mu \mathrm{mol} \mathrm{L}^{-1}$ is diagnostic for decreased liver function, which could be caused by exposure to environmental hazards such as feed contamination (10).

In literature amassed data on haematological values of broiler chickens' blood are limited. Haemoglobin, PCV and eosinophils of male chickens were higher than appropriate parameters of females but the percentage of lymphocytes in females was higher than in male chickens (23). Values for PCV, WBC, heterophils, lymphocytes, and basophils of the males differed from those of the females. Moreover, biochemical parameters, such as ALT, AST, and total protein were also different depending on sex (1).

Even less information is available about the impact of probiotics on haematological parameters of broiler chickens' blood. Male broilers were fed probiotic (Enterococcus faecium) and no significant differences were observed in the number of erythrocytes or lymphocytes between chickens receiving and not receiving the probiotic (14). In this study no apparent effect of $\mathrm{LAB}$ on the physiological condition of broilers 
as might be manifested by changes in haematological parameters was observed and the marked parameters were within the standard range of values $(6,15)$.

Many studies have so far confirmed the ability of Lactobacillus spp. to reduce the growth of undesirable microorganisms in the gastrointestinal tract of broiler chickens. The probiotic strain (L. johnsonii) was used in drinking water, feed and sprayed on litter or administered directly to the beak, during 21 days of Cobb broiler rearing. The bacterium had a significant lessening effect on Clostridium perfringens and Enterobacteriaceae in the small intestine (17).

In another study the probiotics (L. crispatus, L. salivarius, and L. johnsonii) have been shown to have an effect on increasing the total number of anaerobic and lactic bacteria and decreasing the number of Enterobacteriaceae in the small intestine of Cobb broiler chickens (18). The literature provides a further account of L. johnsonii: chickens were infected with Salmonella sofia while receiving probiotic L. johnsonii directly to the beak. Probiotic bacteria were shown to significantly reduce the number of Clostridium perfringens and Salmonella sofia in the gastrointestinal tract of birds compared to the control group not receiving probiotics (19).

In conclusion, the positive effect of the addition to diets of a bacterial preparation consisting of the two potentially probiotic lactic acid bacteria strains: Lactobacillus plantarum K KKP 592/p and Lactobacillus rhamnosus KKP 825 on performance parameters is evidenced in the first feeding period (starter feed). However, feeding chickens with bacteria does not have a significant effect on the final body weight, total feed intake, or feed conversion.

It can also be assumed that feeding broiler chickens with LAB addition influences mortality by reducing the number of deaths caused by various diseases. Moreover, feeding chickens with a bacterial preparation has a positive impact on the intestinal microbiota, due to inhibition of the growth of Salmonella and Clostridium in the intestine.

The safety of the proposed bacterial feed additive was attested to by the failure of a dose of bacterial additive ten times higher than the maximum recommended to have any greater influence on examined health indicators, such as biochemical and haematological parameters of blood, than the maximum recommended dose.

Conflict of Interests Statement: The authors declare that there is no conflict of interests regarding the publication of this article.

Financial Disclosure Statement: The research was done with resources in the possession of the Department of Fermentation Technology, prof. W. Dąbrowski Institute of Agricultural and Food Biotechnology, Warsaw.
Animal Rights Statement: None required.

\section{References}

1. Abdi-Hachesoo B., Talebi A., Asri-Rezaei S., Basaki M.: Sex related differences in biochemical and hematological parameters of adult indigenous chickens in Northwest of Iran. J Anim Sci Adv 2013, 3, 512-516.

2. Albokhadaim I., Althnainan T., El-Bahr S.: Investigation of selected biochemical parameters of local chickens with different age and sex in Al-ahsa, Saudi Arabia. Pakistan J Biol Sci 2012, $15,827-832$.

3. Arslan M., Ozcan M., Matur E., Coteliogliu U., Ergul E.: The effect of vitamin $\mathrm{E}$ on some blood parameters in broilers. Turk J Vet Anim Sci 25, 2001, 711-716.

4. Binek M., Kizerwetter-Świda M., Cisek A., Rzewuska M., Chrobak-Chmiel D., Gieryńska M.: Mechanisms of maintenance of intestinal homeostasis by autochthonic microbiota and probiotics. Med Weter 2016, 72, 611-615. doi: 10.21521/mw.5575.

5. Brzóska F., Buluchevskij S., Stecka K., Śliwiński B.: The effects of lactic acid bacteria and mannan oligosaccharide, with or without fumaric acid, on chicken performance, slaughter yield and digestive tract microflora. J Anim Feed Sci 2007, 16, 241-251.

6. Clinical Diagnostic Division. Veterinary reference guide: A summary of reference intervals for use with KODAK EKTACHEM products, 1990, Rochester (NY): Eastman Kodak Company.

7. EFSA Scientific opinion. Technical guidance. Tolerance and efficacy studies in target animals. EFSA J 2011, 9, 15, doi:10.2903/j.efsa.2011.2175.

8. Grela E., Kowalczyk-Pecka D., Hanczakowska E., Matras J.: Effect of inulin and a probiotic supplement in the diet of pigs on selected traits of the gastrointestinal microbiome. Med Weter 2016, 72, 448-452.

9. Harr K.: Clinical chemistry of companion avian species: A review. Vet Clin Path, 2002, 31, 140-151.

10. Harr K.: Diagnostic value of biochemistry. In: Clinical avian medicine. Volume II, edited by Spix Publishing Inc., Palm Beach, USA, 2005, pp. 612-630.

11. Hrnčár C., Weis J., Mindek S., Bujko J.: Effect of probiotic addition in drinking water on body weight and body measurements of broiler chickens. Anim Sci Biotechnol 2014, 47, 249-253.

12. Kaceci T., Col R.: Haematological and biochemical values of the blood of pheasants (Phasianus colchicus) of different ages. Turk J Vet Anim Sci 2011, 35, 149-156, doi:10.3906/vet-0910-13.

13. Klebaniuk R., Grela E., Kowalczuk-Vasilev E., Florek M., Góźdź J., Pecka S., Danek-Majewska A.: Wpływ ekologicznych dodatków ziołowych w żywieniu zwierząt na ich zdrowotność. In: Wyniki badań z zakresu rolnictwa ekologicznego w 2011 roku. Ministerstwo Rolnictwa i Rozwoju Wsi, 2011, Warszawa, ISBN: 978-83-62178-52-0.

14. Lan R., Lee S., Kim I.: Effects of Enterococcus faecium SLB 120 on growth performance, blood parameters, relative organ weight, breast muscle meat quality, excreta microbiota shedding and noxious gas emission in broilers. Poult Sci 2017, 96, 3246-3253.

15. Mazurkiewicz M.: Choroby drobiu. Agriculture University, Wrocław, 2015, ISBN: 83-89189-76-3.

16. Murshed M., Abudabos A.: Effects of the dietary inclusion of a probiotic, a prebiotic or their combinations on the growth performance of broiler chickens. Rev Brasil Ciencia Avicola 2015, 17, 99-104.

17. Olnood C., Beski S., Choct M., Iji P.: Novel probiotics: their effects on growth performance, gut development, microbial community and activity of broiler chickens. Anim Nutr 2015, 1, $184-191$. 
18. Olnood C., Beski S., Iji P., Choct M.: Delivery routes for probiotics. Effects on broiler performance, intestinal morphology and gut microflora. Anim Nutr 2015, 1, 192-202.

19. Olnood C., Beski S., Choct M., Iji P.: Use of Lactobacillus johnsonii in broilers challenger with Salmonella sofia. Anim Nutr 2015, 1, 203-212.

20. Patyra E., Kwiatek K.: Probiotic feed additives. Med Weter 2013, 69, 225-230.

21. Scientific Opinion on the update of the list of QPS-recommended biological agents intentionally added to food or feed as notified to EFSA. EFSA J 2017, 15, 4664.

22. Seifi K., Torshizi M., Rahimi S., Kazemifard M.: Efficiency of early, single-dose probiotic administration methods on performance, small intestinal morphology, blood biochemistry, and immune response of Japanese quail. Poult Sci 2017, 96, 2151-2158.

23. Simaraks S., Chinrasri O., Aengwanic S.: Haematological, electrolyte and serum biochemical values of the Thai indigenous chicken (Gallus domesticus) in Northeastern Thailand. Song Klanakarin J Sci Technol 2004, 26, 425-430.

24. Timmerman H., Veldman A., van den Elsen E., Rombouts F., Beynen A.: Mortality and growth performance of broilers given drinking water supplemented with chicken-specific probiotics. Poultry Sci 2010, 85, 1383-1388. 